\title{
Preparation and Characterization of a New Desulfurizer and Its Performance on Removal of $\mathrm{SO}_{2}$
}

\author{
Ting Zhang, Junqing Li, Shurong Yu*, Yi Wang \\ School of Petrol-Chemical Engineering, Lanzhou University of Technology, Lanzhou, China \\ Email: zhangting@lut.cn, qing 5975@qq.com, “yusr@lut.cn, wangyi@lut.cn
}

Received January 2014

\begin{abstract}
Sulfur dioxide is one of the major pollutants resulting from fuel combustion. In this study, $\mathrm{CaO}$ and attapulgite were utilized as raw material for synthesizing $\mathrm{CaO} /$ attapulgite (CaO/ATP) desulfurizer. The physicochemical characteristics of CaO/ATP desulfurizer were evaluated by various techniques such as XRD, SEM, FT-IR. The performance of samples was studied in dynamic conditions. Major factors affecting on desulfurization such as weight ratio of $\mathrm{CaO}$ to total, types of modifiers, roasting time and temperature were investigated. The desulfurization agent synthesized under optimal synthesis conditions with $\mathrm{CaO}$ content of $30 \mathrm{wt} \%$ and $\mathrm{NaOH}$ modifier, and the desulfurization roasting time of 2 hours and roasting temperature of $600^{\circ} \mathrm{C}$, exhibit sulfur tolerance of 10.15 $w t \%$. This desulfurizer with excellent absorbency and catalysis of desulfurization, economical and environment-friendly, could be especially useful in industrial applications.
\end{abstract}

\section{Keywords}

Attapulgite; $\mathrm{CaO}$; Desulfurization; $\mathrm{SO}_{2}$; Adsorption

\section{Introduction}

Sulfur dioxide $\left(\mathrm{SO}_{2}\right)$ emission from coal-fired power plants and refinery operations is one of the most important pollution among other pollutants. Discharge of $\mathrm{SO}_{2}$ from various sources can easily create air pollution and cause harmful effects on living things and the environment. For instance, it causes acid rain affecting negatively on plant and animals (Aytar, 2011; Cao, 1996; Chen, 2003).

It is noted that the dry processes are generally advantageous over the wet systems in terms of secondary treatment of wastes produced during wet methods. So because of their simplicity and relatively low cost, dry sorption technologies are applied more than the wet methods. Application of calcium-based sorbents, spray dry flue gas desulfurization, metal oxides sorption and activated carbon or coke processes are the main dry sorption processes used for $\mathrm{SO}_{2}$ and $\mathrm{NO}_{\mathrm{x}}$ removal (Chen, 2003).

Lime/gyp method is a conventional dry desulfurizing method, which uses $\mathrm{CaO}$ or $\mathrm{Ca}(\mathrm{OH})_{2}$ as desulfurizers.

*Corresponding author. 
The lime/gyp method is considered to be more effective and cheaper than other desulfurizing methods, such as activate carbon adsorption and Claus recycle, etc. But the calcium-based desulfurizer has a big problem: It is easy to scaling during the process of desulfurization, because $\mathrm{CaSO}_{4}$, whose molar volume is three times as much as $\mathrm{CaO}$, is generated, and the micro pore of desulfurizer would be soon jammed by $\mathrm{CaSO}_{4}$, which prevent the reaction and decreased $\mathrm{SO}_{2}$ removal efficiency (Chen, 2004; Frost, 1998; Görkem, 2006; Hernández-Maldonado, 2005).

In the field of dry and regenerable sorbents, considerable attention has been devoted to activated carbon or activated coke due to their large adsorption capacity of $\mathrm{SO}_{2}$ at near room temperatures (Li, 2007; Li, 2008). Much work has also been done on metal oxides such as $\mathrm{CuO}, \mathrm{Fe}_{2} \mathrm{O}_{3}, \mathrm{MnO}, \mathrm{CaO}, \mathrm{Co}_{3} \mathrm{O}_{4}, \mathrm{ZnO}$ and $\mathrm{CeO}_{2}$ for $\mathrm{H}_{2} \mathrm{~S}$ or $\mathrm{SO}_{2}$ capture at higher temperatures (Lin, 1998). Despite that the metal oxides alone exhibit high sulfur sorption capacity, their performance and life time are adversely affected by problems such as sintering, evaporation, and mechanical disintegrations. To overcome these problems, $\mathrm{Al}_{2} \mathrm{O}_{3}$ and natural zeolites were added to metal oxides or their mixtures as structure stabilizer (Liu, 2011; Ma, 2003; Pan, 2005). Jianrong Ma et al. (Cao, 1996) investigated a novel regenerable Fe/activated coke (AC) desulfurizer prepared by impregnation of $\mathrm{Fe}\left(\mathrm{NO}_{3}\right)_{3}$ on an activated coke. Experiment results showed that at $200^{\circ} \mathrm{C}$ the $\mathrm{SO}_{2}$ adsorption capacity of the $\mathrm{Fe} / \mathrm{AC}$ was higher than that of $\mathrm{AC}$ or $\mathrm{Fe}_{2} \mathrm{O}_{3}$.

Attapulgite (or palygorskite-as it often called) is a crystalline hydrated magnesium aluminum silicate with unique three-dimensional structure and has a fibrous morphology. Attapulgite has the structural formula $\mathrm{Si}_{8} \mathrm{O}_{20} \mathrm{Mg}_{5}(\mathrm{Al})(\mathrm{OH})_{2}\left(\mathrm{H}_{2} \mathrm{O}\right)_{4} \cdot 4 \mathrm{H}_{2} \mathrm{O}$. The distinguishing feature of its structure is that the Si-O tetrahedral form long strips, each an amphibole unit wide, on alternate sides of the oxygen sheet in a manner which confers a regular corrugated Si-O structure. The formulas are written as such to indicate the two types of water present; magnesium coordinated water and adsorbed water. The structure of the mineral results in zeolite-like channels, which are approximately $3.7 \times 6.0$ and $5.6 \times 11.0 \AA$ wide, respectively. These channels may be filled with water or organic molecules. The water is partly arranged in these channels and water molecules are also bound to the magnesium cations of the $\mathrm{Mg}(\mathrm{Al}, \mathrm{Fe})$ brucite-like ribbon edges that border the channels running along the length of the crystals. Specific surface areas of about $200 \mathrm{~m}^{2} / \mathrm{g}$ may, therefore, result form fine particle size rather than significant contributions from internal channel surface (Perderiset, 1988; Shen, 2012; Wang, 2005). Because of its structural morphology, attapulgite has received considerable attention with regard to the adsorption of organics on the clay surface and to their use as support for catalysts (Wang, 2011; Wieckowska, 1995; Yan, 2002).

In this study, $\mathrm{CaO}$ and attapulgite were utilized as raw material for synthesizing $\mathrm{CaO} /$ attapulgite (CaO/ATP) desulfurizer. Major factors affecting on desulfurization such as weight ratio of $\mathrm{CaO}$ to total, types of modifiers, roasting time and temperature were investigated.

\section{Experimental}

\subsection{Material and Equipment}

Attapulgite clay came from Linze County, Gansu Province, China (60-mash sieve, specific surface area $110 \sim$ $150 \mathrm{~m}^{2} / \mathrm{g}$ ), with ATP content of 31\% 57\%, illite and kaolinite content of $18 \% \sim 23 \%$, quartz and feldspar content of $15 \% \sim 25 \%$, dolomite and montmorillonite content of trace. Its chemical components (\%) are as follows: $\mathrm{SiO}_{2}$, 57.61; $\mathrm{Al}_{2} \mathrm{O}_{3}, 14.06 ; \mathrm{MgO}, 1.10 ; \mathrm{CaO}, 5.26 ; \mathrm{Fe}_{2} \mathrm{O}_{3}, 4.96 ; \mathrm{K}_{2} \mathrm{O}, 2.57 ; \mathrm{Na}_{2} \mathrm{O}, 1.41 ; \mathrm{Ti}, 0.3873 ; \mathrm{Mn}, 0.0603 ;$ P, 0.0585; Sr, 0.0451; Ba, 0.0424; Zr, 0.0197; V, 0.0093; Cr, 0.0071; Zn, 0.0067; La, 0.0041; Ni, 0.0032; Cu, 0.0030; Y, 0.0024; Pb, 0.0015; Th, 0.0014; Nb, 0.0013; Co, 0.0010. The other reagents supplied by their manufacturers was all analytical pure.

\subsection{Preparation Method of the Desulfurizer}

$\mathrm{CaO}$, ATP and some water were mixed and well-distributed at a certain ratio. The mixture was aged for a day, shaped, and dried in the oven at the temperature of $105^{\circ} \mathrm{C}$. The samples were roasted in the high temperature oven at $600^{\circ} \mathrm{C}$ for 2 hours, then cooled. The CaO/ATP desulfurizer samples were obtained.

\subsection{Characterization and Analysis}

SEM was utilized to determine the crystal morphology and chemical element composition. Measurements were made on a JSM-5500 SEM instrument using a digital imaging process. FT-IR was used to confirm the chemical groups in the prepared CaO/ATP desulfurizer. Measurements were made on a Nicolet AVTAR 360 FT-IR spectrometer after samples were mixed with $300 \mathrm{mg}$ of spectroscopic grade $\mathrm{KBr}$ and ground in an agate mortar. The 
crystalline form of the samples was identified by a Panalytical X'Pert PRO XRD instrument (Cu Ka radiation), operating at $40 \mathrm{kV}$ and $30 \mathrm{~mA}$. Surface area, pore volume, and pore size distribution were obtained on a ASAP2010 BET apparatus.

\subsection{Determining the Properties of the Ca0/ATP Desulfurizer}

The ability of desulphurization of $\mathrm{CaO} / \mathrm{ATP}$ desulfurizer was determined by the experiment equipment showed in Figure 1. The experimental conditions can be seen in Table 1. $\mathrm{SO}_{2}$ gas went through the little desulfurizing tower continuously and was absorbed and transferred by $\mathrm{CaO} / \mathrm{ATP}$ desulfurizer. $\mathrm{SO}_{2}$ concentration both at the inlet and at the outlet were determined ever few minutes until the desulfurizer was fully penetrated $\left(\mathrm{SO}_{2} \mathrm{Con}^{-}\right.$ centration at the inlet equals to that at the outlet). Then the desulfurization efficiency curves (penetrating curves) were obtained and the sulfur tolerance $(S)$ was calculated by following formula:

$$
S=\frac{G_{a}-G_{b}}{G_{b}} \times 100 \%
$$

$G_{a}$ - the weight of the desulphurizer after desulphurization;

$G_{b}$-the weight of the desulphurizer before desulphurization.

\section{Results and Discussion}

\subsection{Characterization of the Synthesized Samples}

The phase structures of samples were investigated by XRD, and the obtained results are shown in Figure 2 and Figure 3. XRD patterns of the samples prepared with different $\mathrm{CaO}$ content are contrasted with those of ATP. Samples $\mathrm{CaO} / \mathrm{ATP}$ with different $\mathrm{CaO}$ content showed the characteristic peaks $\left(26.8^{\circ}, 29.9^{\circ}, 39.6^{\circ}, 43.3^{\circ}, 47.6^{\circ}\right.$,

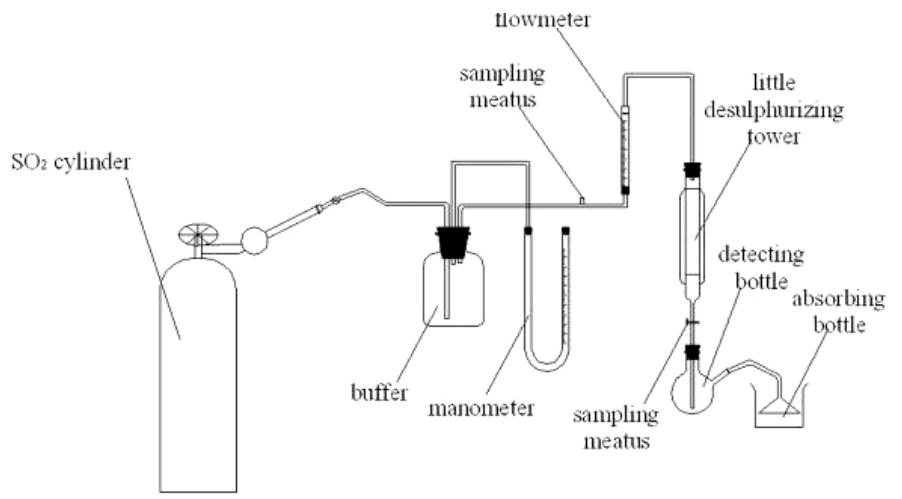

Figure 1. Experimental equipment.

Table 1. Characteristics of experimental conditions.

\begin{tabular}{cc}
\hline Gas & $\mathrm{SO}_{2}$ \\
Temperature & $20^{\circ} \mathrm{C}$ \\
Pressure & Normal \\
Desulfurizer & $\mathrm{CaO} / \mathrm{ATP}$ \\
Column length $(\mathrm{m})$ & 0.20 \\
Column diameter $(\mathrm{m})$ & 0.02 \\
Particle diameter $(\mathrm{m})$ & 0.003 \\
Total porosity & 0.34 \\
Apparent density $\left(\mathrm{kg} / \mathrm{m}^{3}\right)$ & 398.089 \\
BET surface area $\left(\mathrm{m}^{2} / \mathrm{g}\right)$ & 206.9 \\
\hline
\end{tabular}




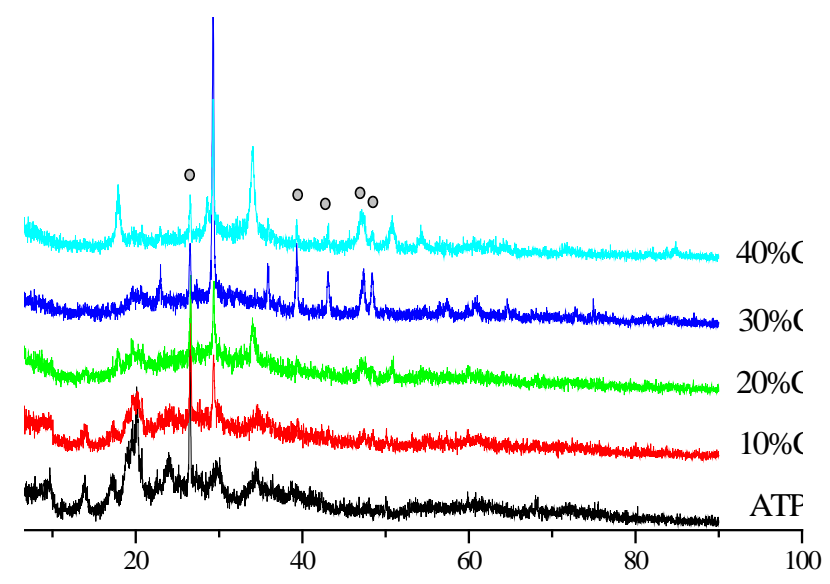

Figure 2. XRD patterns of ATP and $\mathrm{CaO} / \mathrm{ATP}$ samples with different $\mathrm{CaO}$ content $(\mathrm{O}-\mathrm{CaO})$.

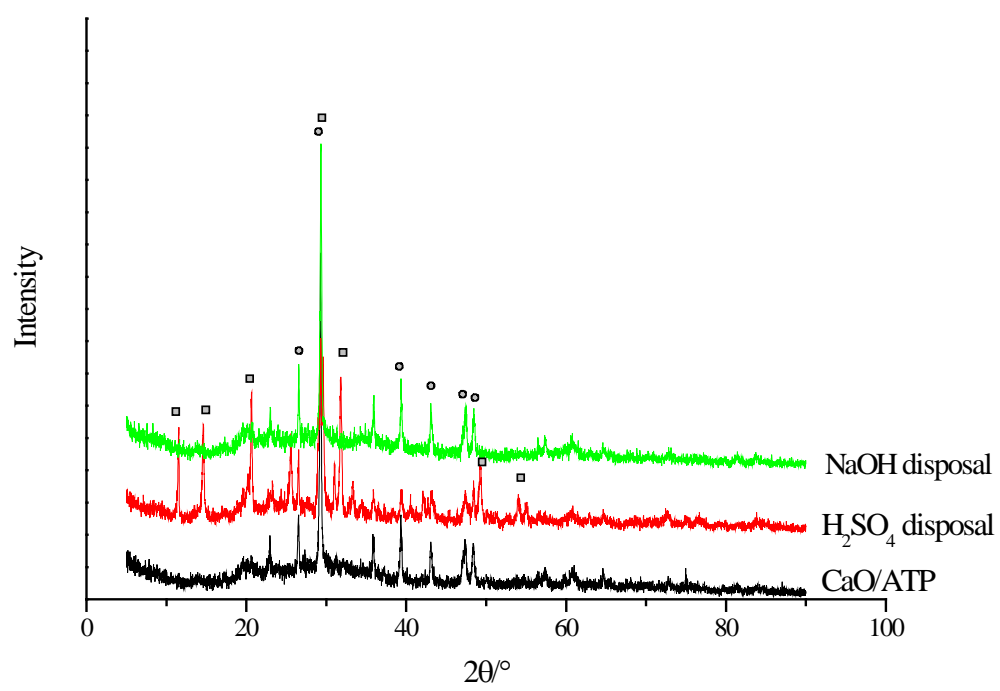

Figure 3. XRD patterns of $\mathrm{CaO} / \mathrm{ATP}$ samples with different modifier ( $\square-$ $\left.\mathrm{CaSO}_{4}, \circ-\mathrm{CaO}\right)$.

$48.4^{\circ}$ ) of cubic spinel structure known from bulk $\mathrm{CaO}$ phase. The intensity of some characteristic peaks of $\mathrm{CaO}$ of $\mathrm{CaO} / \mathrm{ATP}$ sample became stronger along with $\mathrm{CaO}$ content increasing.

Figure 3 showed XRD patterns of $\mathrm{CaO} / \mathrm{ATP}$ samples were disposed by $\mathrm{H}_{2} \mathrm{SO}_{4}, \mathrm{NaOH}$ respectively. From Figure 3 we can see that the samples which were disposed by $\mathrm{NaOH}$ did not change remarkably compared with the samples which were not disposed. The main reaction of that is ion exchange. But when $\mathrm{H}_{2} \mathrm{SO}_{4}$ was used as modifier, $\mathrm{CaO}$ reacted with $\mathrm{H}_{2} \mathrm{SO}_{4}$ and generated $\mathrm{CaSO}_{4}$.

SEM micrographs were collected to illustrate the morphologies of ATP, CaO/ATP, modified samples by $\mathrm{MgCl}_{2}, \mathrm{H}_{2} \mathrm{SO}_{4}$ or $\mathrm{NaOH}$, as depicted in Figure 4. Rod-shaped particles with lengths of $500 \sim 700 \mathrm{~nm}$ and widths of $100 \sim 150 \mathrm{~nm}$ are visible (Figure 2(a)). After the introduction of $\mathrm{CaO}$ species into ATP, rod-shaped crystal still can be seen, but the surface area decreased (Figure 2(b)). Morphological observations of CaO/ATP modified by $\mathrm{NaOH}$ is shown in Figure 2(c), which we cannot see the rod-shaped particles because $\mathrm{NaOH}$ destroyed three-dimensional space structure of ATP (Zhang, 2005), the surface area increased instead. While the sample modified by $\mathrm{H}_{2} \mathrm{SO}_{4}$, which can be seen in Figure 2(d), its surface presented a chaotic condition.

The FT-IR results of CaO/ATP (different roasting temperature) can be seen in Figure 5. The strong wide absorption bands appeared at $3440 \mathrm{~cm}^{-1}$ associated with the surface hydroxyl groups. The weak sharp absorption 


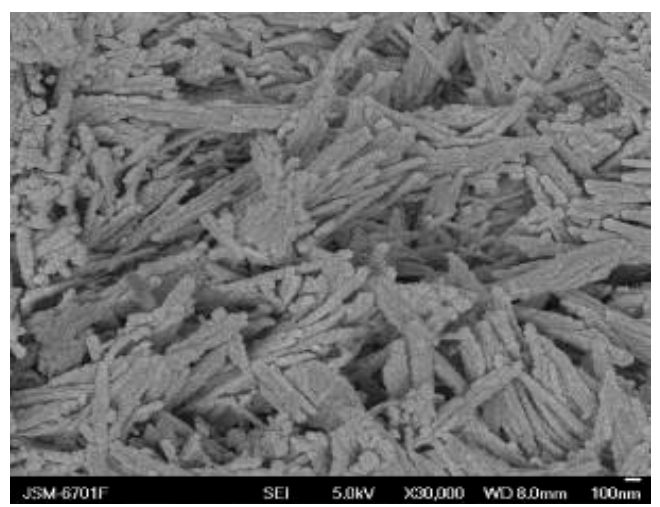

(a)

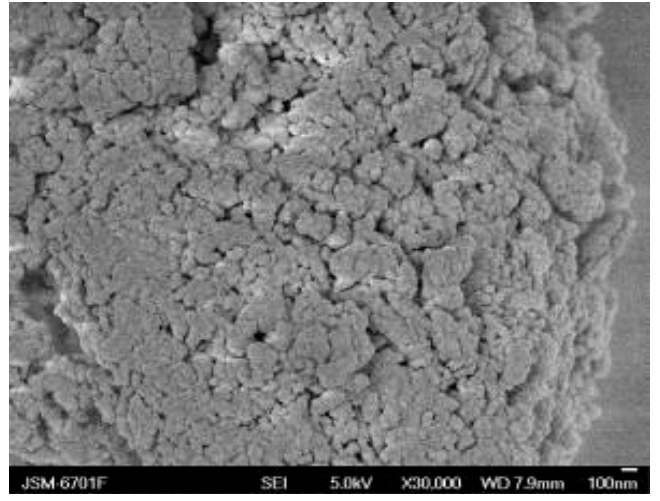

(c)

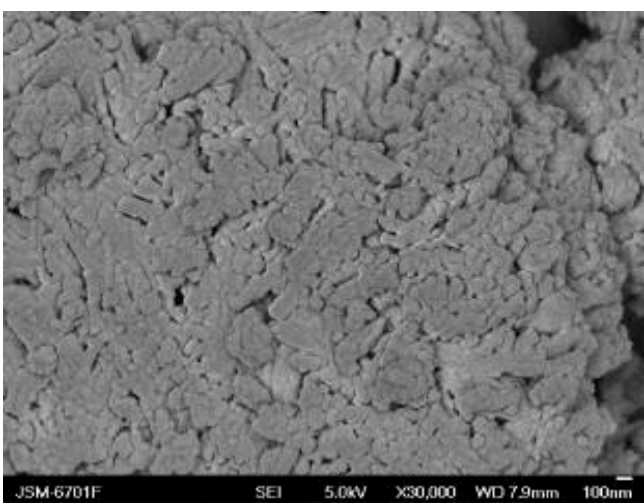

(b)

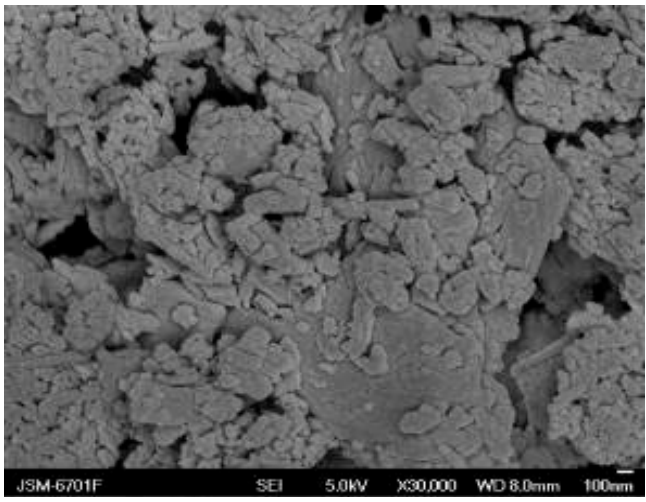

(d)

Figure 4. SEM micrographs of ATP, CaO/ATP, CaO/ATP modified samples by $\mathrm{H}_{2} \mathrm{SO}_{4}$ or $\mathrm{NaOH}$. (a) ATP; (b) $\mathrm{CaO} / \mathrm{ATP}$; (c) $\mathrm{CaO} / \mathrm{ATP}$ modified by $\mathrm{NaOH}$; (d) $\mathrm{CaO} / \mathrm{ATP}$ modified by $\mathrm{H}_{2} \mathrm{SO}_{4}$.

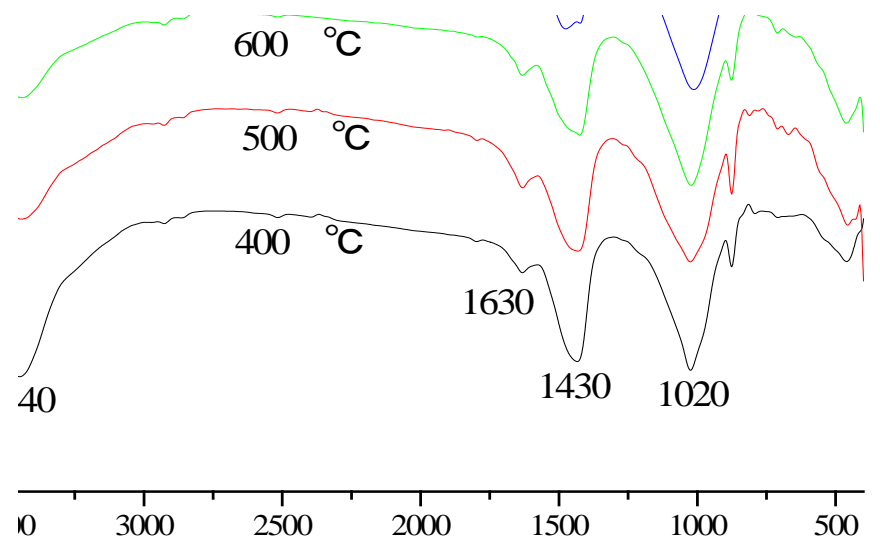

Figure 5. FT-IR results of CaO/ATP (different roasting temperature).

bands at $1630 \mathrm{~cm}^{-1}$ is flexural vibrations of water H-O-H. The strong wide absorption bands at $1020 \mathrm{~cm}^{-1}$ is dissymmetry stretching vibrations of Si-O-Si, and the absorption bands at $777 \mathrm{~cm}^{-1}$ and $476 \mathrm{~cm}^{-1}$ are symmetry stretching and flexural vibrations of Si-O. The strong wide absorption bands appeared at $3440 \mathrm{~cm}^{-1}$ became weak when increasing roasting temperature from $400^{\circ} \mathrm{C}$ to $700^{\circ} \mathrm{C}$, for zeolitic water, crystal water and constitution water of ATP crystal will decrease when temperature increase. Crystal structure changed at high temperature. Over $600^{\circ} \mathrm{C}$, zeolitic duct was destroyed, and zeolitic water disappeared. 


\section{2. $\mathrm{SO}_{2}$ Desulfurizing Experiment by CaO/ATP Desulfurizer}

Except ATP, $\mathrm{CaO}$ was another main component of the desulfurizer. Its content would influent sulfate efficiency. The results were presented in Figure 6 and Figure 7. The $\mathrm{SO}_{2}$ removal efficiency represents the ratio of $\mathrm{SO}_{2}$ concentration at the inlet subtracting that at the outlet to that of inlet feed. Thus, the efficiency curves also indicate the penetrating curves. With increasing content of $\mathrm{CaO}$, the penetrating time and sulfur tolerance were gradually increased. It was because $\mathrm{CaO}$ was basic oxide, which could react with acidic gas $\mathrm{SO}_{2}$ quickly. In fact, the desulurizer has two effects on $\mathrm{SO}_{2}$, ATP adsorbed $\mathrm{SO}_{2}$ and $\mathrm{CaO}$ transferred it to sulfate. The higher $\mathrm{CaO}$ content was, the more $\mathrm{SO}_{2}$ was transferred. Meanwhile, $\mathrm{CaO}$ content could not be too high, that would cause mechanical intensity of the desulfurizer decreased. As a result, $\mathrm{CaO}$ content should be about $30 \mathrm{wt} \%$, the effect of desulfurization of the samples was better.

ATP is often modified by acid, such as sulfur acid and hydrochloric acid. When acid was dissociated in aqueous solution, $\mathrm{H}^{+}$was produced and exchanged with $\mathrm{K}^{+}, \mathrm{Na}^{+}, \mathrm{Ca}^{2+}$ of ATP to enlarge pore volume of that. In this study, $\mathrm{H}_{2} \mathrm{SO}_{4}$ and $\mathrm{NaOH}$ were used for $\mathrm{CaO} / \mathrm{ATP}$ modifying, and the result can be seen in Figure 8. Because ATP was corporated with $\mathrm{CaO}, \mathrm{H}_{2} \mathrm{SO}_{4}$ reacted with $\mathrm{CaO}$ and generated $\mathrm{CaSO}_{4}$, which blocked the micropore and reduced its activities. The samples modified by $\mathrm{NaOH}$ had higher surface area so that the higher sulfur tolerance can be obtained.

Roasting temperature and time will influence the sulfur tolerance, as we saw from Figure 9 and Figure 10. At

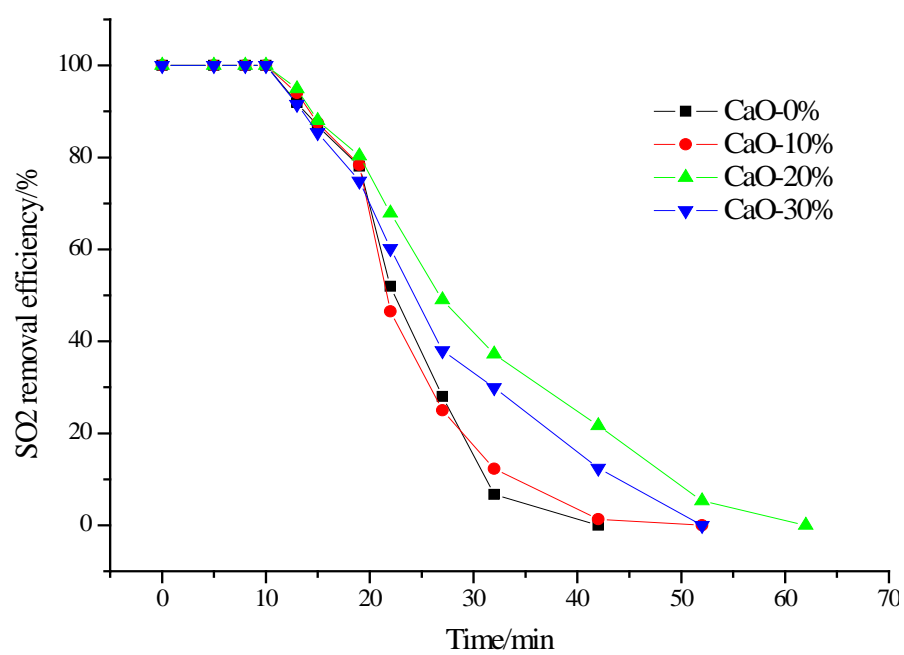

Figure 6. Influences of $\mathrm{CaO}$ content on $\mathrm{SO}_{2}$ removal efficiency.

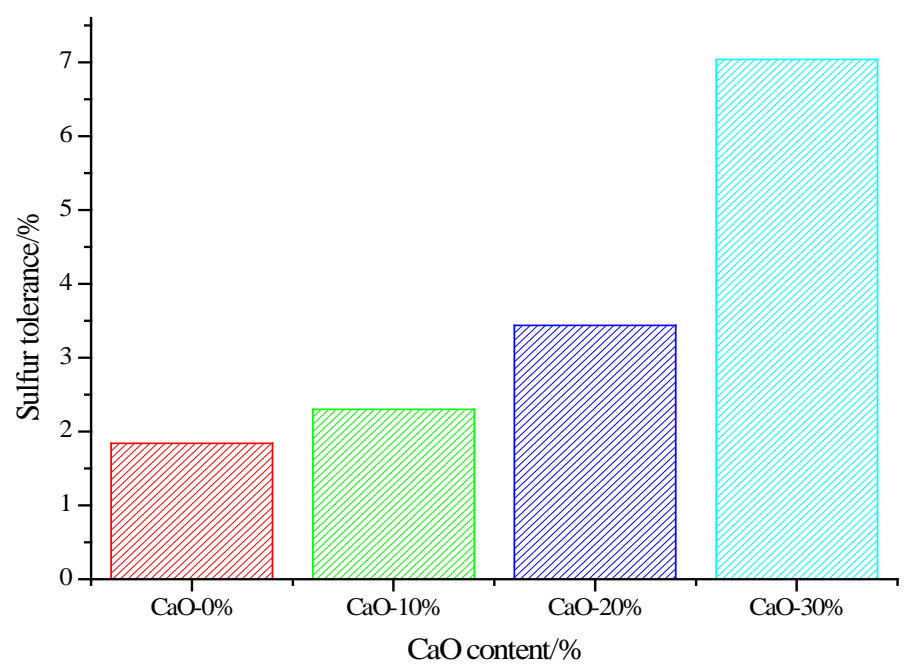

Figure 7. Influences of $\mathrm{CaO}$ content on sulfur tolerance. 


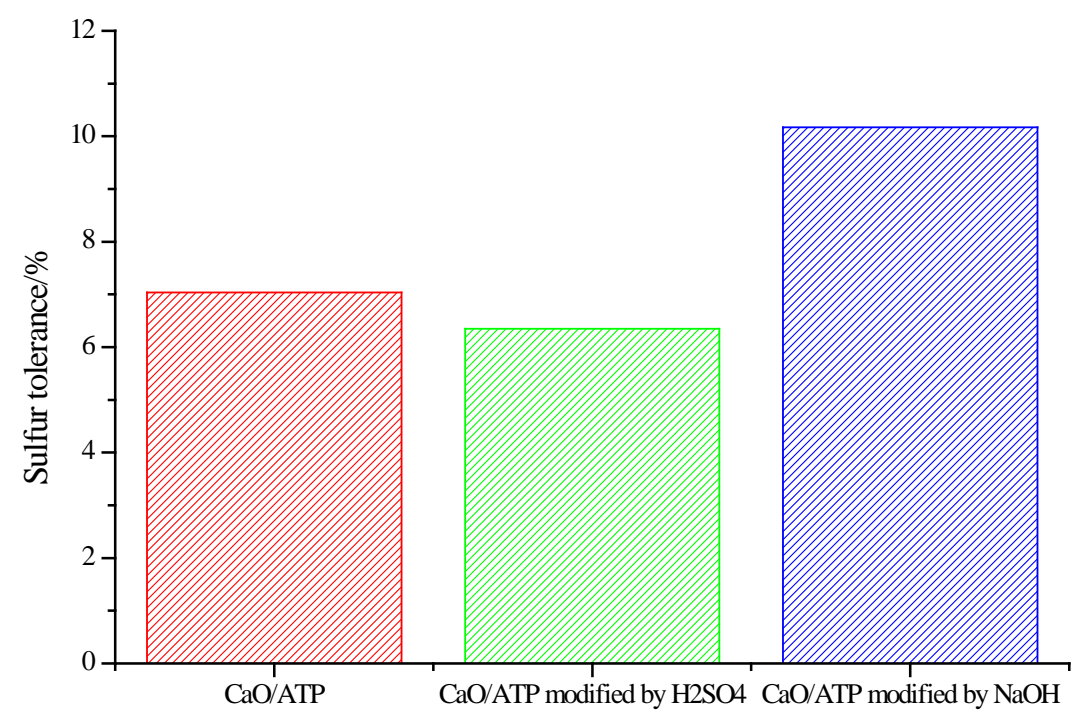

Figure 8. Influences of modifier on sulfur tolerance.

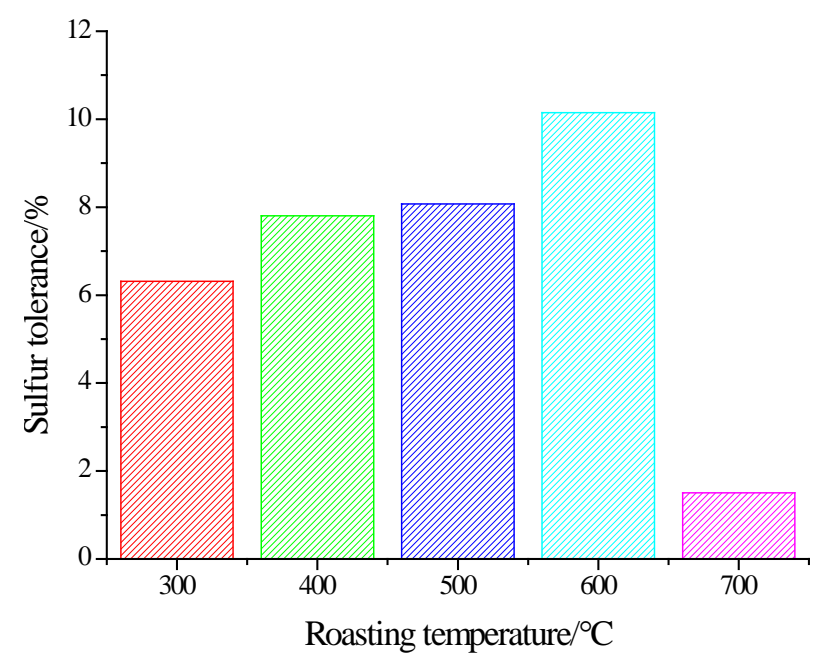

Figure 9. Influences of roasting temperature on sulfur tolerance.

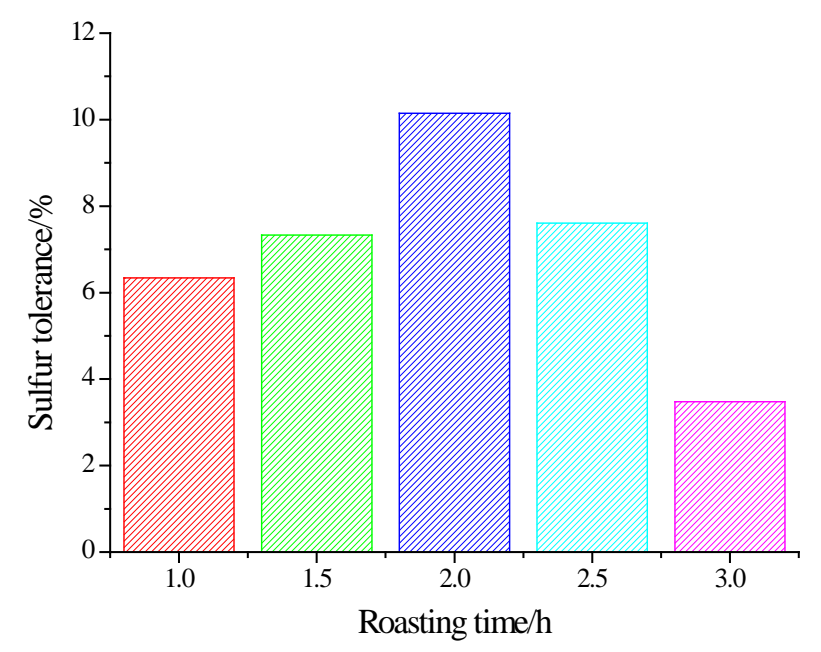

Figure 10. Influences of roasting time on sulfur tolerance. 
$600^{\circ} \mathrm{C}$ and roasting sample 2 hours, highest sulfur tolerance (10.15\%) was achieved. It is known from Figure 5 that duct was destroyed when roasting over $600^{\circ} \mathrm{C}$, which will make the surface area of samples decrease. Roasting time will also influence the sulfur tolerance. The CaO/ATP samples were roasted to clot gradually. When roasted over 2 hours, the pore canal of samples would collapse because of losing water excessively.

\section{Conclusion}

A new CaO/attapulgite desulfurization agent was synthesized by mixing of $\mathrm{CaO}$ and attapulgite directly. The optimum synthesizing and operating conditions were as follows: weight ratio of $\mathrm{CaO}$ to attapulgite, 3:7; types of modifiers, $\mathrm{NaOH}(1 \mathrm{~mol} / \mathrm{L})$; roasting temperature and time, $600^{\circ} \mathrm{C}$ and 2 hours; weight ratio of water to $\mathrm{CaO} / \mathrm{ATP}$ desufurizer, 20 - $30 \mathrm{wt} \%$. The desufurizer synthesized and operated under optimal synthesis conditions exhibited sulfur tolerance of $10.15 \mathrm{wt} \%$.

This new approach showed promising in utilizing natural resource of Gansu, China, such as attapulgite in the production of desulfurization agent, which could significantly reduce the production cost and make the technique quite environmental friendly.

\section{Acknowledgements}

This work was financially supported by the National Natural Science Foundation of China (Grant No. 51302123).

\section{References}

Aytar, P., Gedikli, S., Şam, M., Ünal, A., Çabuk, A., Kolankaya, N., \& Yürüm, A. (2011). Desulphurization of Some LowRank Turkish Lignites with Crude Laccase Produced from Trametes Versicolor ATCC 200801. Fuel Processing Technology, 92, 71-76. http://dx.doi.org/10.1016/j.fuproc.2010.08.022

Cao, E., Bryant, R., \& Williams, D. J. A. (1996). Electrochemical Properties of Na-Attapulgite. Journal of Colloid and Interface Science, 179, 143-150. http://dx.doi.org/10.1006/jcis.1996.0196

Chen, B., \& Zhang, X. X. (2003). The Research Development of the Numerical Model of Single-Particle Dry Method Desulfurization. Industrial Boiler, 77, 16-19.

Chen, B., Jin, H., \& Zhang, X. X. (2003). Original Uneven Porosity Desulphurization Model Research of Small Particle. Journal of Lanzhou University, 39, 41-43.

Chen, B., Jin, H., \& Zhang, X. X. (2004). A Mathematic Model of Non-Homogenous Original Porosity for Dry method Desulfurization. Environmental Pollution Prevention, 26, 46-47.

Frost, R. L., Cash, G. A., Kloprogge, J. T. et al. (1998). Rocky Mountain Leather', Sepiolite Andattapulgite-An Infrared Emission Spectroscopic Study. Vibrational Spectroscopy, 16, 173-184. http://dx.doi.org/10.1016/S0924-2031(98)00014-9

Görkem, B., \& Oğuz, H. (2006). Development of an Active Sorbent from Fly Ash for Dry Desulphurization of Simulated Flue Gas in a Fluidized-Bed Reactor. Chemical Engineering Journal, 119, 147-152. http://dx.doi.org/10.1016/j.cej.2006.03.018

Hernández-Maldonado, A. J., Qi, G. S., \& Yang, R. T. (2005). Desulfurization of Commercial Fuels by $\pi$-Complexation: Monolayer $\mathrm{CuCl} / \gamma-\mathrm{Al}_{2} \mathrm{O}_{3}$. Applied Catalysis B: Environmental, 61, 236-242. http://dx.doi.org/10.1016/j.apcatb.2005.05.012

Li, A., Zhang, J. P., \& Wang, A. Q. (2007). Utilization of Starch and Clay for the Preparation of Superabsorbent Composite. J. Bior. Tech., 98, 327-332. http://dx.doi.org/10.1016/j.biortech.2005.12.026

Li, J. J., Kobayashi, N., \& Hu, Y. Q. (2008). The Activated Coke Preparation for $\mathrm{SO}_{2}$ Adsorption by Using Flue Gas from Coal Power Plant. Chemical Engineering and Processing, 47, 118-127. http://dx.doi.org/10.1016/j.cep.2007.08.001

Lin, Y. S., \& Deng, S. G. (1998). Removal of Trace Sulfur Dioxide from Gas Stream by Regenerative Sorption Processes. Separation and Purification Technology, 13, 65-77. http://dx.doi.org/10.1016/S1383-5866(97)00062-2

Liu, B. S., Wei, X. N., Zhan, Y. P., Chang, R. Z., Subhan, F., \& Au, C. T. (2011). Preparation and Desulfurization Performance of LaMeOx/SBA-15 for Hot Coal Gas. Applied Catalysis B: Environmental, 102, 27-36. http://dx.doi.org/10.1016/j.apcatb.2010.11.020

Ma, J. R., Liu, Z. Y., Liu, S. J., \& Zhu, Z. P. (2003). A Regenerable Fe/AC Desulfurizer for $\mathrm{SO}_{2}$ Adsorption at Low Temperatures. Applied Catalysis B: Environmental, 45, 301-309. http://dx.doi.org/10.1016/S0926-3373(03)00176-0

Pan, Y. G., Perales, J. F., Velo, E., \&Puigjaner, L. (2005). Kinetic Behaviour of Iron Oxide Sorbent in Hot Gas Desulfurization. Fuel, 84, 1105-1109. http://dx.doi.org/10.1016/j.fuel.2004.11.025 
Perderiset, M., Baillif, P., \& Jaurand, M. C. (1988). Chemical Analysis and Photoelectron Spectroscopy of the Adsorption of Macromolecules on the Surface of Attapulgite. Journal of Colloid and Interface Science, 121, 381-391. http://dx.doi.org/10.1016/0021-9797(88)90441-9

Shen, Y. F., Sun, T. H., \& Jia, J. P. (2012). A Novel Desulphurization Process of Coal Water Slurry via Sodium Metaborate Electroreduction in the Alkaline System. Fuel, 96, 250-256. http://dx.doi.org/10.1016/j.fuel.2012.01.003

Wang, L., \& Sheng, J. (2005). Preparation and Properties of Polypropylene/Org-Attapulgite Nanocomposites. Polymer Journal, 46, 6243-6249. http://dx.doi.org/10.1016/j.polymer.2005.05.067

Wang, Y. P., Liu, Y., Dong, Y. H., \& Ma, Y. J. (2011). Adsorption of Ammonia Nitrogen on Modified Palygorskites an d Zeolite in Waste Water. Applied Chemical Industry, 40, 985-992.

Wieckowska, J. (1995). Catalytic and Adsorptive Desulphurization of Gases. Catalysis Today, 24, 405-465. http://dx.doi.org/10.1016/0920-5861(95)00021-7

Yan, Y., Peng, X. F., Jia, L. et al. (2002) Study on the Distributed Pore characteristic of Dry Flue Gas Desulfurization. Energy environment, 20, 38-41.

Zhang, J., Chen, H., \& Wang, A. (2005). Study on Superabsorbent Composite. III. Swelling Behaviors of Polyacrylamide/ Attapulgite Composite Based on Acidified Attapulgite and Organo-Attapulgite. European Polymer Journal, 41, 24342442. http://dx.doi.org/10.1016/j.eurpolymj.2005.03.022 